\title{
PENGAWASAN HAKIM AGUNG DAN HAKIM KONSTITUSI OLEH KOMISI YUDISIAL
}

\author{
(Analisis Terhadap Putusan Mahkamah Konstitusi No.005/PUU-IV/2006 \\ Tentang Yudisial Review UU No.22 Tahun 2004 Tentang Komisi Yudisial)
}

\author{
Jesi Aryanto \\ Fakultas Hukum Universitas YARSI \\ Email : arya_mesuji@yahoo.co.id \\ aryamesuji@gmail.com
}

\begin{abstract}
Chapter 1 Article 3 of the 1945 Constitution stipulates that the State of Indonesia shall be a state based on the rule of law, and thus one of the underlying principles is that the State should provide the court with the power of judgment, free from interventions from other institutions to guarantee that the institution well functions to enforce the law and to serve justice. Law does not merely refer to imperative articles or 'das sollen' obligations; however, it should be perceived as a sub-system which, in reality ('das sein'), can be determined by politics, not only in the formulation processes but also in its implementation. There have been 31 supreme judges who file for a judicial review of the Law No. 22 of 2004 on Judicial Commission for the Constitution. It can be clearly inferred that such a move-claimed to be initiated individually - is mere tactic for it is obvious that those judges in the Supreme Court somehow feel uncomfortable with Judicial Commission's maneuvers. And since the Supreme Court has no legal standing for any cases in the Constitutional Court, it is the individuals of the Supreme Court who seemingly make the move.
\end{abstract}

Keywords : Das Sollen, Das Sein, Judicial Review, Legal Standing, Intervention, Judges, Dispute

\begin{abstract}
Abstrak
Pasal 1 ayat (3) UUD 1945 menegaskan bahwa Indonesia adalah Negara hukum, maka salah satu prinsip negara hukum adalah adanya jaminan penyelenggaraan kekuasaan kehakiman yang merdeka, bebas dari pengaruh kekuasaan lainnya untuk menyelenggarakan peradilan guna menegakkan hukum dan keadilan. Hukum bukan hanya berarti pasal-pasal yang bersifat imperatif atau keharusankeharusan yang bersifat das sollen, melainkan harus dipandang sebagai subsistem yang dalam kenyataan (das sein) dapat ditentukan oleh politik, baik dalam perumusan materi dan pasal-pasalnya maupun dalam implementasi dan penegakannya. 31 orang hakim kemudian menggugat judicial review UU No. 22 tahun 2004 tentang Komisi Yudisial terhadap UUD. Bahwa yang menggugat adalah pribadi-pribadi hakim agung itu hanyalah taktik saja, sebab jika dilihat dari suasana dan sikap-sikap petinggi Mahkamah Agung tampak jelas Mahkamah Agung memang merasa gerah dengan sepak terjang Komisi Yudisial, hanya saja
\end{abstract}


karena Mahkamah Agung secara institusi tidak mempunyai legal standing atau tidak dapat menjadi pihak dalam sengketa di Mahkamah Konstitusi maka yang dimajukan (sekurang-kurangnya dibiarkan dan didorong maju) adalah para hakim agung secara perseorangan.

Kata Kunci : Das Sollen, Das Sein, Judicial Review, Legal Standing, Intervensi, Judges, Dispute.

\section{PENDAHULUAN}

Indonesia adalah negara hukum yang salah satu prinsipnya adalah kekuasaan kehakiman yang merdeka. Prinsip ini menghendaki kekuasaan kehakiman yang bebas dari campur tangan pihak manapun dan dalam bentuk apapun, sehingga dalam menjalankan tugas dan kewajibannya ada jaminan ketidakberpihakan kekuasaan kehakiman kecuali terhadap hukum dan keadilan. ${ }^{1}$ Prinsip kekuasaan kehakiman yang merdeka telah ditegaskan dalam amandemen ke-tiga UUD RI Tahun 1945 Pasal 24 ayat (1) dinyatakan kekuasaan kehakiman merupakan kekuasaan yang merdeka untuk menyelenggarakan peradilan guna menegakkan hukum dan keadilan. Berdasarkan UUD 1945 Indonesia tidak menganut secara penuh paham Trias Politica dan pemisahan kekuasaan, namun pelembagaan berbagai kekuasaan negara di Indonesia jelas menunjukkan adanya keterpengaruhan pada paham Trias Politica. Dan khusus untuk kekuasaan kehakiman telah dinyatakan secara tegas sebagai kekuasaan negara yang terpisah dari kekuasaan-kekuasaan negara lainnya. ${ }^{2}$

Komisi Yudisial (KY) bukan merupakan pemegang kekuasaan kehakiman, namun sebagai lembaga pembantu (state auxiliary organ). Dalam konstitusi diatur bahwa KY merupakan lembaga yang bersifat mandiri yang berwenang mengusulkan pengangkatan Hakim Agung dan mempunyai kewenagan lain dalam rangka menjaga dan menegakkan kehormatan, keluhuran martabat, serta perilaku hakim (Pasal 24 B ayat 1 UUD 1945). Sebenarnya, ide dasar pembentukan KY dilatarbelakangi kekhawatiran akan timbulnya tirani yudisial pasca pemberlakuan sistem satu atap di Mahkamah Agung (MA) dan pemberian kemandirian dan

\footnotetext{
${ }^{1}$ Komisi Yudisial Republik Indonesia, Bunga Rampai: Komisi Yudisial dan Reformasi Peradilan, (Jakarta: Komisi Yudisial, 2007, hal. 197.

${ }^{2}$ Lihat Sri Soemantri, Bunga Rampai Hokum Tata Negara Indonesia, 1978, dan Mahfud MD, Membangun Politik Hukum, Menegakkan Konstitusi, 2006
} 
kemerdekaan kepada institusi pemegang kekuasaan kehakiman ini. Sehingga para anggota DPR/MPR RI sebagai representasi dari rakyat menilai perlunya dibentuk KY (judicial committee) sebagai lembaga pengawas eksternal terhadap kekuasaan kehakiman. $^{3}$

Hubungan antara satu lembaga dengan lembaga yang lain diikat oleh prinsip checks and balances, di mana lembaga-lembaga tersebut diakui sederajat tetapi saling mengendalikan satu sama lain. Sebagai akibat adanya mekanisme hubungan yang sederajat itu, timbul kemungkinan dalam melaksanakan kewenangannya masing-masing terdapat perselisihan dalam menafsirkan amanat UUD. Jikalau timbul persengketaan pendapat semacam itu, diperlukan organ tersendiri yang diserahi tugas untuk memutus final atas hal itu. Dalam sistem yang telah diadopsikan dalam UUD 1945, mekanisme penyelesaian sengketa kewenangan demikian dilakukan melalui proses peradilan tata negara, yaitu melalui lembaga yang dibentuk tersendiri dengan nama Mahkamah Konstitusi (MK).

Hukum bukan hanya bersifat imperatif atau keharusan (das sollen), tetapi harus dipandang sebagai subsistem yang dalam kenyataan (das sein) dapat ditentukan oleh politik, baik dalam perumusan materi dan pasal-pasalnya maupun dalam implementasi dan penegakannya. ${ }^{4} \mathrm{MK}$ sesuai ketentuan Pasal 24C ayat (1) UUD 1945 yang dirinci dalam Pasal 10 ayat (1) huruf a UU No. 24 Tahun 2003 tentang Mahkamah Konstitusi, mempunyai wewenang menguji UU terhadap UUD 1945. Selain perubahan yang menyangkut kelembagaan penyelenggaraan kekuasaan kehakiman sebagaimana dikemukakan di atas, UUD 1945 telah mengintroduksi suatu lembaga baru yang berkaitan erat dengan penyelenggaraan kekuasaan kehakiman (judicative power) yaitu KY.

Setelah perubahan UUD 1945 maka keberadaan KY terdapat dalam Pasal 24A ayat (3) dan Pasal 24B ayat (1) UUD 1945. Pasal 24A ayat (3) merupakan mekanisme pencalonan Hakim Agung yang diusulkan oleh KY kepada DPR

\footnotetext{
${ }^{3}$ Lihat keterangan para saksi dari mantan Anggota Panitia Ad Hoc (PAH) I Badan Pekerja MPR dalam putusan Mahkamah Konstitusi Nomor: 005/PUU-IV/2006 dalam perkara permohonan uji materi terhadap UU No. 22 Tahun 2004 tentang Komisi Yudisial.

${ }^{4}$ Satya Arinanto, Kumpulan Materi Kuliah Politik Hukum (disusun dari berbagai sumber kepustakaan), (Jakarta: FH-UI, 2003).
} 
untuk mendapat persetujuan dan ditetapkan sebagai Hakim Agung oleh Presiden. Sedangkan Pasal 24B ayat (1) UUD 1945 adalah tentang kemandirian serta kewenangan KY yang bersifat mandiri yang berwenang mengusulkan pengangkatan Hakim Agung dan mempunyai wewenang lain dalam rangka menjaga dan menegakkan kehormatan keluhuran martabat serta perilaku hakim.

Bahwa UUD 1945 telah memberikan landasan hukum yang kuat bagi reformasi dibidang peradilan yaitu dengan lebih mengefektifkan fungsi pengawasan baik pengawasan internal maupun eksternal kepada Hakim Agung pada MA, Hakim Konstitusi pada MK, dan para Hakim pada semua lingkungan badan peradilan di Indonesia. Pengawasan internal dilaksanakan oleh organ/badan yang dibentuk oleh lembaga itu sendiri yang diberikan tugas untuk melakukan pengawasan kepada Hakim. Misalnya pada MA terdapat Ketua Muda Bidang Pengawasan, sedangkan pengawasan eksternal sesuai ketentuan UUD 1945 dilakukan oleh Komisi Yudisial (KY).

Merupakan fakta hukum, selama ini kewenangan-kewenangan KY dijalankan tanpa ada satu halangan apapun dan para hakim yang dipanggil oleh KY tidak pernah dilarang oleh MA dan para hakim yang dinilai oleh KY mungkin tidak menjalankan profesinya dengan baik dan dinilai melakukan unprofesional conduct telah diusulkan oleh KY sesuai dengan kewenangan yang ada kepadanya. Dari uraian tersebut di atas, nampak jelas adanya kehendak yang kuat untuk menciptakan kekuasaan kehakiman yang bebas, merdeka tanpa campur tangan pihak manapun, yang pada gilirannya diharapkan harkat, martabat dan keluhuran perilaku hakim sebagai pelaku kekuasaan kehakiman dapat terjaga, sehingga kedepan kepercayaan masyarakat terhadap wibawa hukum dapat terwujud dan rasa keadilan pada masyarakat akan menjadi kenyataan.

\section{METODE PENELITIAN}

Dalam penulisan makalah ini, penulis menggunakan metode library research dan field research secara deskriptif, yaitu menguraikan permasalahan yang ada atau terjadi dalam antar lembaga negara berdasarkan referensi dari bukubuku atau bahan-bahan lainnya yang terkait dengan masalah tersebut, serta studi 
kasus dari putusan Mahkamah Konstitusi RI Nomor 005/PPU-IV/2006 tentang Yudisial Review terhadap Komisi Yudisial (KY).

Kemudian bahan-bahan tersebut dipelajari, dikaji secara mendalam untuk kemudian dielaborasi dan disimpulkan untuk mendapatkan hasil dari permasalahan, sehingga dapat diselesaikan dengan solusi yang baik. Mencari titik temu dari tumpang tindih antar lembaga negara. Sehingga apa yang menjadi citacita hukum atau konstitusi dapat terwujud, menjadikan masyarakat yang sejahtera, adil, makmur dan sentosa.

\section{HASIL PENELITIAN}

Hasil dari penelitian ini adalah mendapatkan kepastian tentang implementasi hukum yang berlaku terkait perngawasan Komisi Yudisial (KY) terhadap hakim agung pada MA dan hakim konstitusi pada MK berdasarkan putusan MK No.005/PPU-IV/2006 tentang Yudisial Review terhadap KY yang pada pokoknya menyatakan hakim pada MK tidak dapat diawasi oleh KY karena KY lahir lebih dulu dari MK, dengan demikian tidak mungkin sesuatu yang dipikirkan dan lahir kemudian sudah dicakup untuk diawasi oleh lembaga yang ada lebih dulu.

\section{PEMBAHASAN}

Fenomena yang terjadi dalam sistem ketatanegaraan Indonesia, khususnya terkait dengan hubungan antarlembaga negara yang bisa bersengketa satu dengan lainnya, oleh karena itu perlu adanya mekanisme terhadap penyelesaian sengketa antarlembaga negara yang kewenangannya diberikan oleh UUD 1945, termasuk kaitan dengan kewenangan MK dalam penyelesaian perkara sengketa kewenangan antarlembaga negara. ${ }^{5}$

Sistem pemerintahan dikenal dengan sebutan trias politica merupakan pembagian kekuasaan secara horizontal adalah pembagian kekuasaan menurut fungsinya. Trias politica adalah anggapan bahwa kekuasaan negara terdiri dari

\footnotetext{
${ }^{5}$ Jimly Asshiddiqie, Sengketa Kewenangan Konstitusional Lembaga Negara, Cet. Ke-3, (Jakarta: Konstitusi Press, 2006), hal. V
} 
tiga macam kekuasaan: pertama, kekuasaan legislatif atau kekuasaan membuat undang-undang (rule making function), kedua, kekuasaan eksekutif atau kekuasaan melaksanakan undang-undang (rule application function), ketiga, kekuasaan yudikatif atau kekuasaan mengadili atas pelanggaran undang-undang (rule adjudication function). ${ }^{6}$

Trias politica adalah suatu prinsip normatif bahwa kekuasaan-kekuasaan itu sebaiknya tidak diserahkan kepada orang yang sama untuk mencegah penyalahgunaan kekuasaan oleh pihak yang berkuasa. Dengan demikian diharapkan hak-hak asasi warga negara lebih terjamin. Sistem tata negara Indonesia belum cukup sistematis dan memang harus disempurnakan lagi. Apalagi dengan munculnya berbagai peristiwa yang menunjukan adanya tumpang tindih fungsi dan wewenang pada beberapa lembaga maupun disharmoni antar lembaga, seperti DPR melakukan amandemen UU MK untuk membatasi kewenangan MK agar tidak begitu saja membatalkan undang-undang yang dibuat oleh $\mathrm{DPR}^{7}$ dan kewenangan DPD dibatasi memberi pertimbangan RUU tertentu terhadap DPR. Menurut Jimly Ashidqie, sebenarnya tujuan amandemen UUD 1945 untuk menyelesaikan disharmonisasi, dan untuk menutupi kekurangan UUD 1945 ada tiga cara yaitu, pertama, formal amandemen, kedua, dikembangkan dalam praktik. Dan ketiga, dengan penafsiran konstitusi oleh MK. ${ }^{8}$

Ketidakharmonisan dan keretakan antar lembaga negara tersebut harus direkatkan kembali dengan pemahaman terhadap UUD. ${ }^{9}$ MK selain menguji dan meniadakan sebuah pasal yang tertera dalam UU yang dianggap bertentangan dengan UUD 1945 juga tidak tertutup kemungkinan dapat menambah isi UU (positif legislator), hal ini sesuai dengan pernyataan hakim Konstitusi Dewa Gede Palguna ${ }^{10}$ dan dikuatkan oleh Ketua MK Jimly Asshidiqie.

Sesuai amanat konstitusi pemerintah harus melaksanakan pemerintahan dengan baik sesuai dengan aspirasi rakyat dengan memperhatikan nilai-nilai

\footnotetext{
${ }^{6}$ Miriam Budiadjo, Dasar-dasar Ilmu Politik, (Jakarta: PT. Gramedia Pustaka Utama, 2006), hal. 151

${ }^{7}$ Buletin Komisi Yudisial, Mendorong Terwujudnya Kekuasaan Kehakiman Yang Merdeka, (Volume 1 Februari 2007), hal. 8

${ }^{8}$ Ibid., hal. 7

${ }^{9}$ Buletin Komisi Yudisial, Mendorong Terwujudnya Kekuasaan Kehakiman Yang Merdeka, (Volume 1 Februari 2007), hal. 7

${ }^{10}$ Media Indonesia, Uji Materil UU Pemilu, Kewenangan MK dipersoalkan, (Rabu, 30 April, 2008), hal. 3
} 
norma yang ada dan berlaku, adat istiadat, dan kebudayaan dalam segala aspek kehidupan berbangsa dan bernegara. Berbicara soal jalannya roda pemerintahan tidak terlepas dari aturan-aturan hukum yang menjadi dasar koridor pemerintahan tersebut. Hal ini berarti pemerintah sebagai lembaga eksekutif dan DPR sebagai lembaga legislatif mempunyai peran yang sangat besar dan menentukan dalam komitmen posisi atau fungsi masing-masing, yaitu eksekutif menyelenggarakan pemerintahan yang baik, bersih, jujur dan adil. Sedangkan legislatif merupakan perwakilan dalam mengemban amanat aspirasi rakyat, yang salah satu fungsinya membuat suatu aturan atau UU dengan prinsip melindungi segala kepentingan rakyat dalam kehidupan beragama, berbangsa dan bernegara.

MK yang di desain sebagai lembaga pengawal konstitusi (the Guardian of the Constitution) dan bahkan sebagai lembaga penafsir (the Interpreter of the Constitution). ${ }^{11}$ Namun, apabila suatu UU baik secara formil ataupun materil bertentangan dengan konstitusi, maka MK berwenang untuk menyatakan UU tersebut tidak mengikat/membatalkan untuk umum. Menurut Hans Kelsen, jika parlemen disebut sebagai positive legislator (legislator positif), maka lembaga verfassungsgericht shoft (MK) tak ubah merupakan negative legislator. ${ }^{12}$

Langkah KY yang dengan gerakannya menyorot dan memeriksa hakimhakim yang dilaporkan dan diduga nakal, mulai dari hakim pengadilan negeri, sampai ke hakim agung ternyata meningkatkan gairah masyarakat untuk menyorot dan melaporkan hakim-hakim nakal, meski tidak semua laporan itu benar adanya. Banyak hakim yang kemudian lebih berhati-hati dalam melaksanakan tugasnya. Dalam melakukan seleksi terhadap calon hakim agung pun, terlepas dari kritik dan kontroversi atas produknya, KY sudah memberi sumbangan yang cukup baik terutama untuk memilih yang terbaik dari yang tidak baik serta dalam membuat kontrak moral agar kalau sudah menjadi hakim agung seseorang dapat melaksanakan tugasnya dengan penuh integritas. ${ }^{13}$

\footnotetext{
${ }^{11}$ Jimly Asshiddiqie, Sengketa Kewenangan Konstitusional Lembaga Negara, Cet. Ke-3, (Jakarta: Konstitusi Press, 2006), hal. 11

${ }^{12}$ Ibid.

${ }^{13}$ Komisi Yudisial, Bunga Rampai Komisi Yudisial dan Reformasi Peradilan, (Jakarta: Komisi Yudisial RI, 2007), hal. 4
} 
Tetapi langkah-langkah KY yang cukup memberi harapan ternyata telah menjadi bumerang yang sama sekali tidak diharapkan baik oleh KY sendiri maupun oleh masyarakat. MA yang merasa kewibawaannya diobrak-abrik merasa tersinggung, terutama ketika KY mengundang ketua MA untuk dimintai keterangan dan ketika KY mengundang beberapa hakim agung untuk diperiksa berkenaan dengan masuknya beberapa laporan dari masyarakat. Kalangan hakim banyak yang mengatakan bahwa KY bukannya menjaga martabat hakim melainkan justru menjatuhkan martabat hakim, bahkan mengintervensi kemandirian hakim. $^{14}$

Oleh karena itulah, 31 (tiga puluh satu) orang hakim mengajukan permohonan judicial review UU No.22 tahun 2004 tentang Komisi Yudisial (KY) dan UU No.4 Tahun 2004 tentang Kekuasaan Kehakiman terhadap UUD yang pada pokoknya bersikan tentang 3 (tiga) hal, yaitu:

1. Para Pemohon meminta MK memutus bahwa hakim agung bukanlah bagian dari hakim yang dapat diawasi oleh KY, sebab menurut pasal 24B ayat (1) untuk hakim agung sudah disebutkan KY hanya mengusulkan pencalonannya, sedangkan untuk mengawasi perilaku disebutkan berlaku untuk hakim. Jadi bagi para penggugat harus dibedakan pengertian antara hakim agung dan hakim sehingga isi UU No. 22 Tahun 2004 yang menyamakan keduanya harus dinyatakan bertentangan dengan konstitusi.

2. Para Pemohon meminta agar para hakim konstitusi tidak dijadikan bagian dari pengertian hakim yang dapat diawasi oleh KY karena hakim konstitusi berbeda dari hakim lain dan baru dimasukkan di dalam UUD lebih belakang dari pengaturan tentang KY. ${ }^{15}$ Argumennya ketika KY ditentukan dalam UUD belum ada gagasan tentang hakim konstitusi, sehingga tidak mungkin ketika KY dibentuk sudah terpikir untuk mengawasi hakim konstitusi.

3. Wewenang KY untuk mengawasi para hakim harus dinyatakan bertentangan dengan UUD karena kriterianya tidak jelas dan bersifat eksesif apalagi dalam

\footnotetext{
${ }^{14}$ Ibid., hal. 4-5

${ }^{15}$ Seperti diketahui pengaturan tentang KY dicantumkan di dalam pasal $24 \mathrm{~B}$ sedangkan pengaturan tentang MK dicantumkan dalam pasal 24C.
} 
prakteknya KY sering memeriksa hakim dengan mempersoalkan isi putusan. ${ }^{16}$

Adapun permohonan yudisial review yang diajukan Pemohon selengkapnya sebagai berikut: bahwa para Pemohon telah mengajukan permohonan Pengujian UU No.22 Tahun 2004 tentang Komisi Yudisial dan Pengujian UU No.4 Tahun 2004 tentang Kekuasaan Kehakiman terhadap UUD 1945, dengan surat permohonannya bertanggal 10 Maret 2006 yang diterima dan terdaftar di Kepaniteraan MK RI pada tanggal 14 Oktober 2005, dengan registrasi Nomor 005/PUU-IV/2006. Dalam permohonannya Pemohon beralasan dan menyatakan sebagai berikut:

A. Beberapa ketentuan dalam UU No.22 Tahun 2004 Tentang KY, yaitu ${ }^{17}$ :

1. Pasal 1 butir 5: "Hakim adalah Hakim Agung dan hakim pada badan peradilan disemua lingkungan peradilan yang berada di bawah MA serta hakim MK sebagaimana dimaksud dalam UUD 1945".

2. Pasal 20: "Dalam melaksanakan wewenang sebagaimana dimaksud dalam Pasal 13 huruf b KY mempunyai tugas melakukan pengawasan terhadap perilaku Hakim dalam rangka menegakkan kehormatan dan keluhuran martabat serta menjaga perilaku hakim".

3. Pasal 21: "Untuk kepentingan pelaksanaan kewenangan sebagaimana dimaksud dalam Pasal 13 huruf b, KY bertugas mengajukan usul penjatuhan sanksi terhadap hakim kepada pimpinan MA dan/atau MK”.

4. Pasal 22 ayat (1) huruf e: "Dalam melaksanakan pengawasan sebagaimana dimaksud dalam Pasal 20, KY: membuat laporan hasil pemeriksaan yang berupa rekomendasi dan disampaikan kepada MA dan/atau MK, serta tindasannya disampaikan kepada Presden dan DPR".

Ayat (5): "Dalam hal badan peradilan atau hakim tidak memenuhi kewajiban sebagaimana dimaksud pada ayat (4), MA dan/atau MK wajib

\footnotetext{
${ }^{16} \mathrm{KY}$ sendiri memberikan argument yang dapat dipahami ketika menyatakan bahwa sulit untuk tidak membaca menilai putusan hakim sebab pengaduan yang masuk pada umumnya menyangkut kejanggalan dalam pemeriksaan perkara dan putusan hakim.

${ }^{17}$ Putusan Mahkamah Konstitusu RI No. 005/PUU-IV/2006 tentang Yudisial Review terhadap UU No.22 Tahun 2004 tentang Komisi Yudisial, hal. 18 - 20.
} 
memberikan penetapan berupa paksaan kepada badan peradilan atau hakim untuk memberikan keterangan atau data yang diminta".

5. Pasal 23 ayat (2): "Usul penjatuhan sanksi sebagaimana dimaksud pada ayat (1) huruf a beserta alasan kesalahannya bersifat mengikat, disampaikan oleh KY kepada pimpinan MA dan/atau MK".

Ayat (3): "Usul penjatuhan sanksi sebagaimana dimaksud pada ayat (1) huruf b dan huruf c diserahkan oleh KY kepada MA dan/atau MK”.

Ayat (5): "Dalam hal pembelaan diri ditolak, usul pemberhentian hakim diajukan oleh MA dan/atau MK kepada Presiden paling lambat 14 (empat belas) hari sejak pembelaan diri ditolak oleh Majelis Kehormatan Hakim”.

6. Pasal 24 ayat (1): "Komisi Yudisial dapat mengusulkan kepada MA dan/atau MK untuk memberikan penghargaan kepada hakim atas prestasi dan jasanya dalam menegakkan kehormatan dan keluhuran martabat serta menjaga perilaku Hakim”.

7. Pasal 25 ayat (3): “Keputusan sebagaimana dimaksud pada ayat (2) adalah sah apabila rapat dihadiri oleh sekurang-kurangnya 5 (lima) orang Anggota KY, kecuali keputusan mengenai pengusulan calon Hakim Agung ke DPR dan pengusulan pemberhentian Hakim Agung dan/atau Hakim MK dengan dihadiri seluruh anggota KY”.

Ayat (4): “ Dalam hal terjadi penundaan 3 (tiga) kali berturut-turut atas keputusan mengenai pengusulan calon Hakim Agung ke DPR dan pengusulan pemberhentian Hakim Agung dan/atau Hakim MK maka keputusan dianggap sah apabila dihadiri oleh 5 (lima) orang anggota"

B. Pasal 34 ayat (3) UU No.4 Tahun 2004 tentang Kekuasaan Kehakiman : "Dalam rangka menjaga kehormatan, keluhuran martabat serta perilaku hakim agung dan hakim, pengawasan dilakukan oleh Komisi Yudisial yang diatur dalam undang-undang"

bertentangan dengan Pasal 24B ayat (1) dan Pasal 25 UUD 1945, sebagai berikut: 
Pasal 24B ayat (1): “KY bersifat mandiri yang berwenang mengusulkan pengangkatan hakim agung dan mempunyai wewenang lain dalam rangka menjaga dan menegakkan kehormatan, keluhuran martabat, serta perilaku hakim”.

Pasal 25 : "Syarat-syarat untuk menjadi dan untuk diperhentikan sebagai hakim ditetapkan dengan undang-undang".

Hal-hal yang menjadi alasan Pemohon dalam Permohonan yudisial review sebagaimana telah diuraikan di atas didasarkan pada dasar hukum sebagai berikut $^{18}$ :

a. Pasal 24C ayat (1) UUD 1945 yang menyatakan: "MK berwenang mengadili pada tingkat pertama dan terakhir yang putusannya bersifat final untuk menguji UU terhadap UUD, memutus sengketa kewenangan lembaga Negara yang kewenangannya diberikan oleh UUD, memutus pembubaran partai politik dan memutus perselisihan tentang hasil Pemilihan Umum“;

b. Bahwa Pemohon adalah perorangan warga negara Indonesia sebagai Hakim Agung pada MA yang mempunyai kepentingan hukum dalam permohonan ini karena Pemohon menganggap hak dan kewenangan konstitusional Pemohon dirugikan oleh berlakunya UU No.22 Tahun 2004, khususnya yang berkaitan dengan "pengawasan hakim" yang diatur dalam Bab. III Pasal 20 dan Pasal 22 ayat (1) huruf e dan ayat (5) serta yang berkaitan dengan "usul penjatuhan sanksi” yang diatur dalam Pasal 21, Pasal 23 ayat (2) dan ayat (3) serta ayat (5), Pasal 24 ayat (1) dan Pasal 25 ayat (3) dan ayat (4) dihubungkan dengan Bab. I Pasal 1 butir 5 UU tersebut. Dengan berlakunya Pasal-pasal tersebut menimbulkan kerugian pada para Pemohon sebagai Hakim Agung termasuk juga Hakim MK menjadi atau sebagai objek pengawasan serta dapat diusulkan sebagai objek penjatuhan sanksi oleh KY;

c. Bahwa ketentuan yang diuraikan pada huruf $b$ di atas sangat berkaitan dengan Pasal 34 ayat (3) UU No.4 Tahun 2004 yang menyatakan bahwa "dalam

\footnotetext{
${ }^{18}$ Putusan Mahkamah Konstitusi RI No. 005/PUU-IV/2006 tentang Yudisial Review terhadap UU No.22 Tahun 2004 tentang Komisi Yudisial, hal. 5 - 9.
} 
rangka menjaga kehormatan, keluhuran martabat serta perilaku Hakim Agung dan Hakim, pengawasan dilakukan oleh KY yang diatur dalam UU”;

Kemudian yang menjadi alasan-alasan permohonan pengujian terhadap UU No.22 Tahun 2004 tentang KY dan Pasal 34 ayat (3) UU No.4 Tahun 2004 tentang Kekuasaan Kehakiman :

1). - Bahwa di dalam Pasal 24B ayat (1) UUD 1945 disebutkan sebagai berikut : "KY bersifat mandiri yang berwenang mengusulkan pengangkatan Hakim Agung dan mempunyai wewenang lain dalam rangka menjaga dan menegakkan kehormatan, keluhuran martabat serta perilaku Hakim”;

- Bahwa apabila kalimat tersebut dibaca dalam satu nafas dan konteknya satu sama lain maka bermakna bahwa KY mempunyai kewenangan lain dalam rangka menjaga dan menegakkan kehormatan, keluhuran martabat, serta perilaku hakim adalah dalam rangka melaksanakan kewenangan KY untuk mengusulkan pengangkatan Hakim Agung;

2). Bahwa di dalam Pasal 25 UUD 1945 mengatur bahwa syarat-syarat untuk menjadi dan untuk diberhentikan sebagai Hakim ditetapkan dengan UU yang mengatur tentang hal tersebut yang berbeda untuk Hakim Tingkat I dan Tingkat Banding (UU No.8 Tahun 2004 untuk Peradilan Umum, UU No.9 Tahun 2004 untuk Peradilan Tata Usaha Negara, UU No.7 Tahun 1989 untuk Peradilan Agama, UU No.31 Tahun 1997 untuk Peradilan Militer) serta Hakim Agung (UU No.5 Tahun 2004) dan Mahkamah Konstitusi (UU No.24 Tahun 2003);

Dalam hal ini jelas bahwa kewenangan KY tidak menjangkau Hakim MA dan Hakim MK, karena untuk menjadi Hakim Agung dan Hakim MK tidak seluruhnya berasal dari Hakim Tingkat I dan Hakim Banding;

Lebih jelas lagi bahwa KY tidak berwenang untuk mengadakan pengawasan terhadap Hakim Ad Hoc. Dari sini jelas terlihat bahwa yang dimaksud dengan kata "Hakim" di dalam Pasal 24B UUD 1945 bukan terhadap seluruh Hakim. Berdasarkan hal tersebut, maka yang dimaksudkan oleh Pasal 24B ayat (1) UUD 1945 tentang kewenangan lain dalam rangka menjaga dan 
menegakkan kehormatan, keluhuran martabat, serta perilaku Hakim adalah Hakim yang akan menjadi Hakim Agung pada MA;

3). Bahwa akan tetapi ternyata di dalam UU No.22 Tahun 2004 yaitu:

a. Pasal 20 disebutkan bahwa: "Dalam melaksanakan wewenang sebagaimana dimaksud dalam Pasal 13 huruf b, KY mempunyai tugas melakukan pengawasan terhadap perilaku Hakim dalam rangka menegakkan kehormatan dan keluhuran martabat serta menjaga perilaku Hakim"

b. Pasal 1 butir 5 menentukan bahwa yang dimaksud dengan: "Hakim adalah Hakim Agung dan Hakim pada badan peradilan disemua lingkungan peradilan yang barada dibawah MA serta Hakim MK sebagaimana dimaksud dalam UUD 1945";

Dengan demikian Pasal 1 butir 5 tersebut telah memperluas pengertian Hakim yang diatur dalam Pasal 24B ayat (1) UUD 1945 karena hanya dimaksudkan terhadap Hakim pada badan peradilan di semua lingkungan peradilan di bawah MA saja, tidak meliputi Hakim Agung dan Hakim MK;

c. Di samping kedua Pasal yang disebut di dalam UU No.22 Tahun 2004 tersebut, hal yang sama juga disebut di dalam Pasal 34 ayat (3) UU No.4 Tahun 2004 tentang Kekuasaan Kehakiman yang memberi kewenangan kepada KY untuk melakukan pengawasan Hakim Agung adalah bertentangan dengan Pasal 24B UUD 1945;

4). Bahwa dalam rumusan pasal-pasal yang di sebut dalam angka 3 di atas membawa makna bahwa pengawasan KY terhadap para Hakim pada badan peradilan di semua lingkungan peradilan termasuk di dalamnya Hakim Agung pada MA dan Hakim pada MK jelas bertentangan dengan Pasal 24B UUD 1945, karena yang dimaksud "Hakim" dalam Pasal 24B tersebut tidak meliputi Hakim MA dan Hakim MK;

5). Bahwa secara universal, kewenangan pengawasan $\mathrm{KY}$ tidak menjangkau Hakim Agung pada MA, karena KY adalah merupakan mitra dari MA dalam melakukan pengawasan terhadap para hakim pada badan peradilan di semua lingkungan peradilan yang ada dibawah MA; 
Pasal 32 UU No.5 Tahun 2004 tentang MA yang berbunyi sebagai berikut :

(1) Mahkamah Agung melakukan pengawasan tertinggi terhadap penyelenggaraan peradilan di seтиa lingkungan peradilan dalam menjalankan kekuasaan kehakiman;

(2) Mahkamah Agung mengawasi tingkah laku dan perbuatan pada Hakim di semua lingkungan peradilan dalam menjalankan tugasnya;

Adapun usul penjatuhan sanksi terhadap Hakim menurut Pasal 21 jo Pasal 23 ayat (3) dan ayat (4) dilakukan oleh KY yang diserahkan kepada MA dan kepada Hakim yang akan dijatuhi sanksi pemberhentian diberi kesempatan untuk membela diri dihadapan Majelis Kehormatan Hakim;

6). Bahwa di samping itu khusus mengenai usul pemberhentian terhadap Hakim Agung dilakukan oleh Ketua MA dan kepada Hakim Agung yang bersangkutan diberi kesempatan untuk membela diri lebih dahulu dihadapan Majelis Kehormatan Mahkamah Agung sebagaimana diatur dalam Pasal 12 UU No.5 Tahun 2004 tentang MA, sedang bagi Hakim MK usul pemberhentiannya dilakukan oleh Ketua MK dan kepada Hakim Konstitusi yang bersangkutan diberi kesempatan untuk membela diri lebih dahulu dihadapan Majelis Kohormatan Mahkamah Konstitusi sebagaimana diatur dalam Pasal 23 ayat (3) dan ayat (4) UU No.24 Tahun 2003 tentang MK, tanpa campur tangan dari KY. Hal ini berbeda dengan Hakim pada badan peradilan dibawah MA selain mensyaratkan usul penjatuhan sanksi dari KY, juga Hakim yang bersangkutan diberi kesempatan lebih dahulu untuk membela diri dihadapan Majelis Kehormatan Hakim;

Atas dasar tersebut maka Pasal 21, Pasal 23 ayat (2) dan ayat (3) serta ayat (5), Pasal 24 ayat (1) dan Pasal 25 ayat (3) dan ayat (4) yang mengatur tentang usul penjatuhan sanksi terhadap Hakim Agung dan/atau Hakim MK oleh KY bertentangan dengan Pasal 24B dan Pasal 25 UUD 1945 yang memberi kewenangan kepada MA dan MK untuk membentuk Majelis Kehormatan MA dan/atau Majelis Kehormatan MK;

7). Bahwa oleh karena pengawasan terhadap Hakim Agung dan Hakim MK serta usul penjatuhan sanksi oleh KY tidak termasuk Hakim Agung dan/atau 
Hakim MK, maka sepanjang mengenai "pengawasan dan usul penjatuhan sanksi” terhadap Hakim Agung dan Hakim Konstitusi sebagaimana diatur dalam Pasal-pasal:

- 1 butir 5

- 20, 21, 22 ayat (1) huruf e dan ayat (5), 23 ayat (2) dan ayat (3) serta ayat (5), 24 ayat (1) dan Pasal 25 ayat (3) dan ayat (4) UU No.22 Tahun 2004 tentang KY serta Pasal 34 ayat (3) UU No.4 Tahun 2004 tentang Kekuasaan Kehakiman harus dinyatakan bertentangan dengan Pasal 24B dan Pasal 25 UUD 1945 dan selanjutnya menyatakan bahwa pasal-pasal tersebut tidak mempunyai kekuatan hukum yang mengikat bagi Hakim Agung dan Hakim MK;

Pengawasan KY selama ini yang telah memanggil beberapa Hakim Agung, dalam hubungan dengan perkara yang telah diadilinya. Pemanggilan oleh KY terhadap Hakim Agung Bagir Manan, Marianna Sutadi, Paulus Effendi Lotulung, Parman Suparman, Usman Karim, Harifin A. Tumpa telah mengakibatkan terganggunya hak konstitusional Hakim Agung, ${ }^{19}$ yang dijamin kemerdekaannya oleh UUD 1945. Pemanggilan KY kepada para Hakim Agung tersebut, berpotensi dan akan membawa makna bahwa semua Hakim Agung dapat dipanggil sewaktu-waktu karena memutus suatu perkara. Hal ini akan menghancurkan independensi Hakim Agung yang dijamin UUD 1945;

Bahwa pengawasan oleh KY dengan cara memanggil Hakim Agung karena memutus suatu perkara merupakan sebab-akibat (causal verband), hilangnya atau terganggunya kebebasan Hakim yang dijamin oleh UUD 1945. Bahwa memperluas makna "Hakim" pada Pasal 24B UUD 1945 sebagaimana berdasarkan pada Pasal 1 butir 5 UU No.22 Tahun 2004 tentang KY adalah bertentangan dengan prinsip hukum yang berlaku secara universal yakni prinsip Lex Certa, suatu materi dalam peraturan perundang-undangan tidak dapat diperluas atau ditafsirkan lain selain yang tertulis dalam peraturan perundangan (Lex Stricta), atau dengan kata lain prinsip suatu ketentuan atau perundang-

\footnotetext{
${ }^{19}$ Ibid., hal. 9
} 
undangan tidak dapat diberikan perluasan selain ditentukan secara tegas dan jelas menurut peraturan perundang-undangan. Selain itu, perluasan makna tersebut tidak berdasarkan prinsip Lex Superior Derogate Legi Inferiori, suatu perundangundangan yang lebih rendah tidak boleh bertentangan dengan peraturan perundang-undangan yang lebih tinggi. Begitu pula dalam kaitan "penjatuhan sanksi" pada Pasal 20, 21, 22 ayat (1) huruf e dan ayat (5), 23 ayat (2) dan ayat (3) serta ayat (5), 24 ayat (1) dan 25 ayat (3) dan ayat (4) UU No.22 Tahun 2004 tentang KY, adalah bertentangan dengan asas Lex Certa dan Lex Superior Derogate Legi Inferiori ${ }^{20}$;

Bahwa pada persidangan, Pemerintah telah memberi keterangan sebagai berikut: Pasal 1 ayat (3) UUD 1945 menegaskan bahwa Indonesia adalah Negara hukum. Sejalan dengan ketentuan tersebut maka salah satu prinsip Negara hukum adalah adanya jaminan penyelenggaraan kekuasaan kehakiman yang merdeka, bebas dari pengaruh kekuasaan lainnya untuk menyelenggarakan peradilan guna menegakkan hukum dan keadilan. Bahwa perubahan UUD 1945 telah membawa perubahan dalam kehidupan ketatanegaraan di Indonesia, khususnya dalam pelaksanaan kekuasaan kehakiman (judicative power). Berdasarkan Pasal 24 UUD 1945, ditegaskan bahwa kekuasaan kehakiman dilaksanakan oleh sebuah MA dan badan peradilan yang berada dibawahnya dalam lingkungan peradilan umum, lingkungan peradilan agama, lingkungan peradilan militer, lingkungan peradilan tata usaha Negara, dan oleh sebuah Mahkamah Konstitusi.

Bahwa MA sebagaimana ditentukan dalam UU No.4 Tahun 2004 tentang Kekuasaan Kehakiman, yang lebih dipertegas dalam UU No.5 Tahun 2004 tentang Perubahan atas UU No.14 Tahun 1985 tentang MA, mempunyai wewenang untuk mengadili pada tingkat kasasi, peninjauan kembali (PK) terhadap putusan pengadilan yang telah mempunyai kekuatan hukum tetap, sengketa tentang kewenangan mengadili, menguji peraturan perundang-undangan dibawah UU, dan kewenangan-kewenangan lainnya sebagai ditentukan dan diatur didalam UU. Selain kewenangan tersebut, MA juga mempunyai kewenangan

\footnotetext{
${ }^{20} I b i d$., hal. 10
} 
untuk melakukan pengawasan terhadap jalannya peradilan, tentang pelaksanaan tugas pengadilan dan tingkah laku para hakim disemua lingkungan peradilan.

MK sesuai ketentuan Pasal 24C ayat (1) UUD 1945 yang dirinci dalam Pasal 10 ayat (1) huruf a UU No.24 Tahun 2003 tentang MK, mempunyai wewenang menguji UU terhadap UUD 1945. Selain perubahan yang menyangkut kelembagaan penyelenggaraan kekuasaan kehakiman sebagaimana dikemukakan di atas, UUD 1945 telah mengintroduksi suatu lembaga baru yang berkaitan erat dengan penyelenggaraan kekuasaan kehakiman (judicative power) yaitu Komisi Yudisial (KY).

KY sebagaimana ditentukan dalam Pasal 24B ayat (1) UUD 1945 bahwa: “Komisi Yudisial bersifat mandiri yang berwenang mengusulkan pengangkatan hakim agung dan mempunyai wewenang lain dalam rangka menjaga dan menegakkan kehormatan, keluhuran martabat, serta perilaku hakim”. Kewenangan KY dipertegas dalam UU No.22 Tahun 2004 tentang KY, bahwa KY tersebut kemudian mempunyai kewenangan untuk mengusulkan pengangkatan Hakim Agung kepada DPR dan menegakkan kehormatan dan keluhuran martabat serta menjaga perilaku hakim.

Bahwa UUD 1945 telah memberikan landasan hukum yang kuat bagi reformasi dibidang peradilan yaitu dengan lebih mengefektifkan fungsi pengawasan baik pengawasan internal maupun eksternal kepada Hakim Agung pada MA, Hakim Konstitusi pada MK, dan para Hakim pada semua lingkungan badan peradilan di Indonesia. Pengawasan internal dilaksanakan oleh organ/badan yang dibentuk oleh lembaga itu sendiri yang diberikan tugas untuk melakukan pengawasan kepada Hakim. Misalnya pada MA terdapat Ketua Muda Bidang Pengawasan, sedangkan pengawasan eksternal sesuai ketentuan UUD 1945 dilakukan oleh KY.

Bahkan MA pada persidangan MK tanggal 24 Nopember 2005 yang diwakili oleh Direktur Hukum dan Peradilan MA R.I. sebagaimana dikutip dalam Putusan MK No.017/PUU-III/2005 tanggal 6 Januari 2006 berpendapat bahwa ${ }^{21}$ : "apapun yang dikemukakan oleh para Pemohon dalam kenyataannya sekarang,

\footnotetext{
${ }^{21}$ Putusan MK No.017/PUU-III/2005 tanggal 6 Januari 2006, hal. 37 - 38.
} 
kewenangan yang ada pada MA didasarkan kepada Pasal 32 UU No.14 Tahun 1985 yang tidak dihapuskan atau tidak dirubah oleh UU No.5 Tahun 2004 dengan demikian tetap masih berlaku dimana ditegaskan dan jelas disebutkan bahwa MA melakukan pengawasan tertinggi terhadap penyelenggaraan peradilan di seтиa lingkungan peradilan dalam menjalankan kekuasaan kehakiman dan MA mengawasi tingkah laku dan perbuatan para Hakim di semua lingkungan peradilan dalam menjalankan tugasnya.

Kemudian MA berwenang untuk meminta keterangan tentang hal-hal yang bersangkutan dengan teknis peradilan dari semua lingkungan peradilan. MA juga berwenang memberi petunjuk, teguran, atau peringatan yang dipandang perlu kepada pengadilan di semua lingkungan peradilan. UU menentukan pengawasan dan kewenangan sebagaimana dimaksud, ayat (1) dan (4) tidak boleh mengurangi kebebasan hakim dalam memeriksa dan memutus perkara.

Sedangkan kewenangan yang ada pada KY sudah jelas dan kami melihat bahwa kewenangan yang ada pada MA adalah pengawasan internal dan pengawasan yang dilakukan oleh KY berdasarkan, baik UUD maupun ketentuan dari UU No.22 Tahun 2004 adalah kewenangan eksternal yang diberikan sepenuhnya kepada KY dalam rangka menegakkan kehormatan dan keluhuran martabat serta menjaga perilaku hakim”.

Selain itu, sehubungan dengan anggapan sebagaimana yang menjadi dasar permohonan para Pemohon tersebut, Pemerintah telah menyampaikan keberatan atau bantahan terhadap kebaratan para Pemohon tidak relevan dan memberikan penjelasan sebagai berikut ${ }^{22}$ :

1. Para Pemohon dalam permohonannya beralasan bahwa kalimat yang terdapat dalam Pasal 24B ayat (1) UUD 1945, apabila dibaca dalam satu napas dan konteknya satu sama lain maka bermakna bahwa KY "mempunyai kewenangan lain dalam rangka menjaga dan menegakkan kehormatan, keluhuran martabat serta perilaku hakim adalah dalam rangka

\footnotetext{
${ }^{22}$ Putusan Mahkamah Konstitusi RI No. 005/PUU-IV/2006 tentang Yudisial Review terhadap UU No.22 Tahun 2004 tentang Komisi Yudisial, hal. 20 - 24.
} 
melaksanakan kewenangan KY untuk mengusulkan pengangkatan Hakim Agung",

Terhadap alasan para Pemohon tersebut diatas, dapat dijelaskan hal-hal sebagai berikut :

a. Bahwa berdasarkan teknik penyusunan perundang-undangan maka untuk memperjelas substansi suatu norma digunakan sistem tabulasi, sehingga ketentuan dalam Pasal 24B ayat (1) UUD 1945 mengandung dua kewenangan KY yang berbeda yaitu :

- $\quad$ kewenangan mengusulkan pengangkatan hakim agung; dan

- mempunyai kewewenangan lain dalam rangka menjaga dan menegakkan kehormatan, keluhuran martabat, serta perilaku hakim.

b. Bahwa frase "berwenang mengusulkan pengangkatan hakim agung" dan frase "mempunyai wewenang lain dalam rangka menjaga dan menegakkan kehormatan, keluhuran martabat, serta perilaku hakim" dihubungkan oleh kata hubung "dan". Kata hubung "dan" dalam konteks ini berfungsi sebagai penghubung satuan ujaran (kata, frase, klausula, dan kalimat yang setara), yang termasuk tipe yang sama serta memiliki fungsi yang tidak berbeda (Kamus Besar Bahasa Indonesia, Balai Pustaka, Departemen Pendidikan dan Kebudayaan, 1995).

c. Bahwa secara gramatikal frase "berwenang mengusulkan pengangkatan Hakim Agung", dan frase "mempunyai wewenang lain dalam rangka menjaga dan menegakkan kehormatan, keluhuran martabat serta perilaku hakim" merupakan dua frase yang mempunyai kedudukan yang setara. Sehingga tidak mungkin frase "mempunyai wewenang lain dalam rangka menjaga dan menegakkan kehormatan, keluhuran martabat serta perilaku hakim" sebagai sub-ordinasi dari frase "berwenang mengusulkan pengangkatan Hakim Agung".

d. Bahwa dalam pertimbangan hukum Putusan MK No.017/PUU-III/2005 tanggal 6 Januari 2006, juga telah ditegaskan bahwa kewenangan pengawasan oleh MA bersifat internal, sedangkan pengawasan yang dilakukan oleh KY baik berdasarkan UUD 1945, maupun UU No.22 
Tahun 2004 tentang KY, adalah kewenangan eksternal dalam rangka menegakkan kehormatan dan keluhuran martabat serta menjaga perilaku hakim.

Berdasarkan penjelasan tersebut, Pemerintah berpendapat alasan para Pemohon yang menyatakan bahwa pengertian "mempunyai kewenangan lain dalam rangka menjaga dan menegakkan kehormatan, keluhuran martabat serta perilaku hakim" adalah dalam rangka melaksanakan kewenangan KY yaitu "mengusulkan pengangkatan Hakim Agung" tidak berkaitan dengan konstitusionalitas keberlakuan suatu UU.

2. Menurut para Pemohon ketentuan Pasal 25 UUD 1945 mengatur syarat-syarat untuk menjadi hakim dan untuk diberhentikan sebagai hakim ditetapkan dengan UU, yaitu antara lain: UU No.8 Tahun 2004 (untuk Hakim Tingkat I dan Banding); UU No.9 Tahun 2004 (untuk Hakim Peradilan Tata Usaha Negara); UU No.7 Tahun 1989 (untuk Hakim Peradilan Agama); UU No.31 Tahun 1997 (untuk Hakim Peradilan Militer); UU No.5 Tahun 2004 (untuk Hakim Agung); dan UU No.24 Tahun 2003 (untuk Hakim MK).

Para Pemohon menyimpulkan bahwa kewenangan KY tidak menjangkau Hakim Agung dan Hakim MK karena untuk menjadi Hakim Agung dan Hakim MK tidak seluruhnya berasal dari Hakim Tingkat I dan Hakim Banding. Juga KY tidak berwenang mengawasi hakim Ad Hoc. Sehingga menurut para Pemohon bahwa yang dimaksud "hakim" dalam Pasal 24B ayat (1) UUD 1945, bukan terhadap seluruh Hakim, melainkan Hakim yang akan menjadi Hakim Agung pada MA.

Terhadap alasan para Pemohon tersebut diatas, dapat dijelaskan hal-hal sebagai berikut :

a. Bahwa kesimpulan para Pemohon yang didasarkan pada ketentuanketentuan dalam: UU No.8 Tahun 2004 (untuk Hakim Tingkat I dan Banding), UU No.9 Tahun 2004 (untuk Hakim Peradilan Tata Usaha Negara), UU No.7 Tahun 1989 (untuk Hakim Peradilan Agama), UU No.31 Tahun 1997 (untuk Hakim Peradilan Militer), UU No.5 Tahun 2004 (untuk Hakim Agung), dan UU No.24 Tahun 2003 (untuk Hakim 
MK), merupakan kesimpulan sepihak para Pemohon yang dijadikan dasar untuk menafsirkan kata "hakim" seperti yang tercantum dalam Pasal 24B ayat (1) UUD 1945.

b. Bahwa para Pemohon mengajukan permohonan untuk menguji konsistensi antara UU yang satu dengan UU yang lain, yaitu antara UU No.8 Tahun 2004, UU No.9 Tahun 2004, UU No.7 Tahun 1989, UU No.31 Tahun 1997, UU No.5 Tahun 2004, dan UU No.24 Tahun 2003 terhadap UU No.22 Tahun 2004 tentang KY.

c. Bahwa jika terjadi inkonsistensi antara UU yang satu dengan yang lain yang sifatnya sederajat, maka sesuai dengan asas perundang-undangan yang menyatakan "undang-undang yang kemudian/belakangan mengenyampingkan undang-undang yang berlaku terdahulu (lex posteriore derogat lex priori)", sehingga sepanjang mengatur tentang ketentuan yang sama dan dibuat oleh lembaga yang sama pula, maka semua UU yang dijadikan acuan oleh para Pemohon tersebut di atas dikesampingkan oleh UU No.22 Tahun 2004 karena UU ini diundangkan paling belakangan. Konsekuensinya semua pengertian "hakim" di dalam UU tersebut diatas, harus tunduk pada pengertian hakim yang diatur dalam Pasal 1 angka 5 UU No.22 Tahun 2004 tentang KY.

d. Bahwa perbedaan perekrutan (rekruitmen) antara Hakim Agung dengan Hakim, tidak dapat dijadikan alasan oleh para Pemohon untuk membedakan antara Hakim Agung dengan Hakim, karena setelah menjadi Hakim (Hakim Agung, Hakim Peradilan Umum, Hakim Peradilan Agama dan Hakim Peradilan Militer) kewenangannya sama sebagai pelaksana kekuasaan kehakiman, karenanya tunduk pada lembaga pengawasan eksternal sebagaimana diamanatkan Pasal 24 ayat (2) UUD 1945.

3. Keberatan para Pemohon terhadap ketentuan Pasal 1 angka 5 UU No.22 Tahun 2004 Tentang KY, Pemerintah dapat menjelaskan hal-hal sebagai berikut : 
a. Bahwa RUU tentang KY merupakan salah satu RUU inisiatif DPR-RI dalam rancangan awal rumusan Pasal 1 angka 5 berbunyi: "hakim adalah hakim pada semua badan peradilan di lingkungan peradilan”.

b. Dalam Daftar Inventarisasi Masalah (DIM) yang dibuat Pemerintah, rumusan Pasal 1 angka 5 diusulkan perubahan yang berbunyi :

"hakim adalah Hakim Agung dan hakim pada semua badan peradilan yang berada di bawah Mahkamah Agung meliputi peradilan umum, peradilan agama, peradilan militer dan peradilan tata usaha Negara, serta pengadilan khusus yang berada dalam lingkungan peradilan tersebut”.

c. Bahwa untuk merumuskan ketentuan Pasal 1 angka 5 tersebut, antara Pemerintah dan DPR telah terjadi diskusi dan perdebatan yang cukup alot, intensif, tajam dan dinamis (dibahas selama tiga hari kerja dan tiga kali skorsing). Hal ini bertujuan agar dalam merumuskan ketentuan Pasal 1 angka 5 tersebut jangan sampai memperluas substansi dari ketentuan Pasal 24 ayat (2) dan Pasal 25 UUD 1945.

Dengan demikian, pertimbangan majelis hakim dalm putusan MK didasarkan dengan pendekatan contextualism terhadap ketentuan Pasal 24B ayat(1) UUD 1945. Pendekatan yang dilakukan dalam interpretasi adalah contextualism or purposivism or Englihtened Literalism sebagaimana yang dipaparkan oleh Jan McLeod dalam bukunya Legal Method chapter 21: Modern Interpretation in practice. Pendekatan contextualism mendasarkan pada tiga asas, yaitu $^{23}$ : asas noscitur a sociis, asas ejusdem generis dan asas expressio unius exclusio alterius.

\section{a. Asas Noscitur a Sociis}

Asas ini mengandung makna: a thing is known by its associates (h.279). Hal itu mengandung makna bahwa arti sebuah kata ditentukan oleh konteksnya. Berdasarkan asas ini, makna hakim dalam Pasal 24B ayat (1) UUD 1945

\footnotetext{
${ }^{23}$ Putusan Mahkamah Konstitusi RI No. 005/PUU-IV/2006 tentang Yudisial Review terhadap UU No.22 Tahun 2004 tentang Komisi Yudisial, hal. 76 - 77.
} 
digunakan dalam konteks: dan mempunyai wewenang lain dalam menjaga dan menegakkan kehormatan, keluhuran martabat serta perilaku hakim.

Dengan demikian istilah hakim digunakan untuk wewenang Komisi Yudisial yang lain, yaitu selain mengusulkan pengangkatan hakim agung.

\section{b. Asas Ejusdem Generis}

Asas ini mengandung makna of the same class. Dengan asas ini pertanyaan terkait adalah apakah dalam konteks Pasal 24B ayat (1) UUD 1945, hakim agung termasuk dalam kelompok hakim yang terkait wewenang Komisi Yudisial yang kedua?

Dalam konteks ini hakim agung tidak termasuk kelompok hakim (of the same class) terkait wewenang lain (wewenang kedua) Komisi Yudisial. Andaikata wewenang lain itu termasuk hakim agung dalam konteks Pasal 24B ayat (1) haruslah secara tegas dinyatakan.

Ketentuan Pasal 34 ayat (3) UU No. 4 Tahun 2004 yang menambah rumusan: menjaga kehormatan hakim agung dan hakim adalah inkonstitusional karena Pasal 24B ayat (1) UUD 1945 hanya merumuskan perilaku hakim. Selanjutnya Pasal 1 butir 5 UU No. 22 Tahun. 2004 tentang Komisi Yudisial memperluas lagi sehingga menjangkau juga hakim Mahkamah Konstitusi.

\section{c. Asas Expressio Unius Exclusio Alterius.}

Asas ini mengandung makna bahwa: the expression (or the inclusion) of one thing implies the exclusion of another.

Dengan asas ini berarti dengan berpegang pada makna hakim dalam konteks Pasal 24B ayat (1) tidaklah termasuk hakim agung maka haruslah ditolak ketentuan dalam undang-undang menyangkut kewenangan Komisi Yudisial mengawasi perilaku hakim dengan mengartikan hakim agung dan hakim Mahkamah Konstitusi termasuk pengertian hakim dalam konteks Pasal 24B ayat (1) UUD 1945. UU dimaksud saat ini adalah UU No. 4 Tahun 2004 (Pasal 34 ayat (3)) dan UU No. 22 Tahun 2004 (Pasal 1 butir 5). 
Menurut Pemulis, sebenarnya putusan MK yang membatalkan sebagian kewenangan KY dibidang pengawasan, merupakan langkah yang keliru, karena telah menimbulkan kekosongan hukum. Dan yang lebih parah lagi sebenarnya berhadapan dengan makin tinggi dan makin hebatnya potensi praktek mafia peradilan. Dan kalaupun kewenangan pengawasan prilaku hakim oleh KY itu dianggap ada masalah, MK minimal mengeluarkan putusan sebagaimana putusan tentang UU KPK yang menyatakan Pasal 53 tentang Pengadilan Tipikor dinyatakan tidak berlaku dalam masa maksimal tiga tahun setelah diputus. ${ }^{24}$

Kemudian jika para Pemohon merasa hak-hak konstitusionalnya dirugikan dengan diberlakukannya UU No.22 Tahun 2004 tentang KY dan UU No.4 Tahun 2004 tentang Kekuasaan Kehakiman, maka hal ini perlu dipertanyakan hak konstitusional para Pemohon mana yang dirugikan ?, apakah lembaga MA sebagai pelaku kekuasaan kehakiman itu sendiri atau hakim secara keseluruhan baik dalam lingkungan peradilan umum, tata usaha negara, agama maupun peradilan militer. Sementara itu, berdasarkan Putusan MK No.006/PUU-III/2005, MK telah menentukan 5 (lima) syarat adanya kerugian konstitusional sebagaimana dimaksud dalam Pasal 51 ayat (1) UUMK, sebagai berikut:

a. harus ada hak konstitusional pemohon yang diberikan oleh UUD 1945;

b. hak konstitusional tersebut dianggap dirugikan oleh berlakunya suatu undangundang;

c. kerugian hak konstitusional tersebut bersifat spesifik dan aktual, atau setidaktidaknya bersifat potensial yang menurut penalaran yang wajar dapat dipastikan akan terjadi;

d. ada hubungan sebab akibat (causal verband) antara kerugian hak konstitusional dengan undang-undang yang dimohonkan pengujian;

e. ada kemungkinan bahwa dengan dikabulkannya permohonan, maka kerugian hak konstitusional yang didalilkan tidak akan atau tidak lagi terjadi;

\footnotetext{
${ }^{24}$ Buletin Komisi Yudisial, Mendorong Terwujudnya Kekuasaan Kehakiman Yang Merdeka, (Volume 1 Februari 2007), hal. 5
} 
Maka dalam hal ini, dapat kita pahami bahwa terjadi benturan kepentingan yang dilandasi oleh hasrat peribadi atau individu, dan oknum tertentu yang tidak ingin menjadi obyek pengawasan yang mungkin bisa dikatakan salah satu alasan adalah memang mereka (para pemohon yudisial review) termasuk orang yang tidak bersih, oleh karena itu wajar saja ada perasaan takut dan alergi dengan aturan main yang telah ditentukan dalam undang-undang. Karena kalau merasa bersih seharusnya tidak perlu merasa takut justru harus didukung dalam rangka penegakkan hukum di negara ini. Selain itu, Para pemohon yudisial review mengatasnamakan individu mereka sebagai hakim agung, dan tidak mengatasnamakan lembaga MA. Kalau penulis nilai memang secara hukum sebagai MA sebagai lembaga tidak mempunyai legal standing untuk itu, oleh karena itu mereka tidak mengatasnamakan lembaga atau instansi MA adalah taktik saja, sebab jika dilihat dari suasana sikap-sikap petinggi MA tampak jelas bahwa MA memang merasa gerah dengan sepak terjang KY. Seharusnya dalam hal ini MA sebagai lembaga negara mendinginkan permasalahan, memberi pengertian dan pemahaman kepada anggotanya tentang hak dan kewajiban lembaga negara yang sudah dibentuk dengan UU sebagai sifat yang merupakan check and balances sesama antara lembaga negara.

KY dalam sejarahnya tidak luput dari pujian dan cercaan yang terus bermunculan yang sampai Juli 2007 telah menyebabkan KY berada pada posisi yang menggantung karena setelah wewenangnya untuk melaksanakan fungsi pengawasan dipangkas melalui putusan MK pada Agustus 2006, praktis pekerjaannya hanya menyeleksi calon hakim agung. Itu pun masih menimbulkan kontroversi karena produknya tentang calon hakim agung tahun 2007 banyak yang menilainya tidak berkualitas apalagi Irawady Joenoes, salah seorang anggotanya, memperotes karena keputusan KY ditetapkan dalam rapat yang katanya, sengaja dilakukan tanpa kehadirannya. ${ }^{25}$

Putusan judicial review MK pada Agustus 2006 tentang UU No. 22 Tahun 2004 itu memang agak kompromistis tetapi juga dapat dipersoalkan karena selain

\footnotetext{
${ }^{25}$ Komisi Yudisial Republik Indonesia, Bunga Rampai: Komisi Yudisial dan Reformasi Peradilan, (Jakarta: Komisi Yudisial, 2007), hal. 1.
} 
dianggap mengandung ultra petita ${ }^{26}$ juga bertentangan dengan asas nemo judex in causa sua sekaligus juga tidak sesuai dengan konsepsi hakim yang dimaksud dalam UUD. Hal ini didasarkan dengan beberapa alasan, yaitu :

1. Dinilai kompromistis karena menolak gugatan bahwa hakim agung berada diluar subyek yang dapat diawasi oleh KY, namun hampir semua pedoman pengawasan untuk mengawasi para hakim sebagaimana diatur di dalam UU No. 22 Tahun 2004 dipangkas sehingga meskipun boleh mangawasi tetapi terjadi kekosongan hukum dalam operasionalisasi pengawasan itu sendiri. ${ }^{27}$

2. Dinilai ultra petita dan bias karena salah satu dasar pertimbangan pemangkasan wewenang KY itu didasarkan pada pertentangan (tidak sinkron) ketentuan yang ada antar UU yakni pertentangan UU KY (yang dapat merekomendasikan pemberian sanksi pada hakim) dengan UU lain seperti UU No. 14 Tahun 1985 sebagaimana telah diubah dengan UU No. 5 Tahun 2004 tentang MA dan UU No. 2 Tahun 1986 sebagaimana telah diubah dengan UU No. 8 Tahun 2004 tentang Peradilan Umum yang menentukan bahwa pemberhentian hakim agung dan hakim dilakukan setelah melalui Majelis Kehormatan Mahkamah Agung dan Majelis Kehormatan Hakim. Bias terjadi dan dapat dianggap ultra petita disini karena Mahkamah Konstitusi hanya bisa menguji UU terhadap UUD bukan UU terhadap UU lainnya.

Persoalan belum adanya ketentuan tentang kriteria pelanggaran moral oleh hakim mestinya tidak dapat dijadikan alasan untuk membatalkan kewenangan KY sebab masalah tersebut merupakan ranah legislatif. Lagi pula jika UU tentang KY bertentangan dengan UU lain mengapa isi UU KY yang dibatalkan?

Mengapa tidak diberlakukan ketentuan bahwa hukum yang datang kemudian (UU No. 22 Tahun 2004) menghapus hukum yang terdahulu yakni UU No. 14 Tahun 1985 sebagaimana telah diubah dengan UU No. 5 Tahun 2004 tentang MA dan UU No. 2 Tahun 1986 sebagaimana telah diubah dengan UU

\footnotetext{
${ }^{26}$ Mahfud MD, Perdebatan Hukum Tata Negara Pasca Amandemen UUD 1945, (Jakarta: LP3ES, 2007), atau dilihat juga Komisi Yudisial: Bunga Rampai Komisi Yudisial dan Reformasi Peradilan, hal. 6

${ }^{27}$ Komisi Yudisial, Bunga Rampai Komisi Yudisial dan Reformasi Peradilan, (Jakarta: KY, 2006) hal. 6
} 
No. 8 Tahun 2004 tentang Peradilan Umum sesuai dengan asas lex posteriori derogat lex anteriori?

3. Putusan MK tersebut agak berbenturan juga dengan asas nemo judex in causa sua karena MK memutus hal-hal yang menyangkut kepentingannya sendiri yakni meletakkan hakim konstitusi sebagai subyek yang berada diluar pengawasan KY. Dalam asas ini ditentukan bahwa hakim tidak boleh memutus perkara yang menyangkut dirinya sendiri. Sudah dua kali MK memutus hal-hal yang menyangkut dirinya sendiri. Selain memutus bahwa hakim konstitusi bukanlah bagian dari hakim yang dapat diawasi oleh KY, MK pernah membatalkan ketentuan UU tentang MK yang menentukan bahwa MK hanya boleh melakukan pengujian atas UU yang lahir setelah terbentuknya MK.

Kemudian putusan MK menyatakan bahwa MK boleh menguji semua UU termasuk semua UU yang sudah ada sebelum terbentuknya MK. Selain berbenturan dengan asas nemo judex in causa sua bias putusan MK tidak sesuai dengan ide dan konsep tentang hakim di dalam konstitusi dan tata hukum sebab ide dan konsep dasar hakim adalah semua pejabat yang melaksanakan kekuasaan kehakiman.

Meskipun begitu harus diingat bahwa, terlepas dari benar atau salah, menurut pasal 24C ayat (1) putusan MK itu bersifat mengikat, final and binding, tak dapat dilawan lagi secara hukum. Tegasnya, putusan MK itu belum tentu benar, tetapi sudah pasti mengikat. Kebenaran putusan MK itu bersifat relatif, tergantung pada pilihan perspektif, dalil atau pasal-pasal yang dipergunakan untuk memutus; artinya sebuah putusan MK bisa salah jika yang dipakai untuk memutus adalah perspektif, dalil, dan pasal-pasal lain. Dengan kata lain, seandainya yang menjadi hakim pada MK itu adalah hakim lain yang menggunakan atau mengikuti paradigma, perspektif teori, dan dalil-dalil lain maka putusan bisa berbeda. ${ }^{28}$

Peran dan fungsi dari KY sangat banyak bagi kemaslahatan bangsa dalam menegakkan supremasi hukum dan menjaga kehormatan, keluhuran dan martabat

\footnotetext{
${ }^{28}$ Komisi Yudisial, Bunga Rampai Komisi Yudisial dan Reformasi Peradilan, (Jakarta: KY, 2006) hal. 7
} 
hakim. KY telah menjalankan tugasnya dengan baik, setiap ada atau terima laporan tentang adanya indikasi kecurangan atau kesalahan dari masyarakat atau pihak lainnya langsung dilakukan penyelidikan kebenaran laporan tersebut untuk ditindak lanjuti. Namun sayang, kewenangannya hanya sebatas merekomendasikan sanksi atau hukuman saja, tidak dapat mengeksekusi sanksi tersebut. Karena menurut UU kewenangan tersebut hanya bisa dilakukan oleh MA sebagai eksekutor. Tapi anehnya beberapa kali KY telah merekomendasikan sanksi atau hukuman tersebut tidak digubris oleh MA.

\section{PENUTUP}

\section{A. Kesimpulan}

1. Putusan MK bahwa hakim MK tidak bisa diawasi oleh KY karena KY lahir lebih dulu dari MK itu bisa benar dari perspektif tertentu sebab tidak mungkin sesuatu yang dipikirkan dan lahir kemudian sudah dicakup untuk diawasi oleh lembaga yang ada lebih dulu. Tetapi jika konsep hakim dilihat dri teori tentang tugas-tugas untuk mengadili, siapa pun yang melakukan dan kapan pun dibentuk, maka hakim konstitusi pun harus dipandang sebagai hakim yang juga harus diawasi oleh KY. Jadi tampak jelas bahwa ini tinggal pilihan paradigma dan perpektif teorinya, serta tergantung pada siapa, dan apa yang dimainkan hakim-hakim yang memeriksa dan memutus.

2. Putusan MK bersifat final dan mengikat dan harus dilaksanakan. Bukan karena benar, tetapi karena hal itu sudah diputuskan oleh lembaga yang diberi wewenang oleh konstitusi untuk memutus sengketa tentang itu. Disini berlaku prinsip: "hukmul hakim yarfaul khilaf", putusan hakim menyelesaikan semua pertentangan, terlepas dari soal kita senang atau tidak senang. Dengan demikian putusan MK terhadap KY sudah dipengaruhi politik, sehingga kepantingan politik lah yang dikedepankan, oleh karena itu putusan tersebut banyak dinilai tidak populis oleh sebagian kalangan, karena berdampak kekosongan hukum, dan menimbulkan masalah baru. 
3. Putusan MK hanya mendasarkan pada asas kepastian hukum saja tanpa didasarkan dengan dua asa lainnya yaitu asas keadilan sesuai dengan ketentuan pasal 24 ayat (1) dan pasal 28D ayat (1) serta asas kemanfaatan sesuai dengan ketentuan pasal $28 \mathrm{H}$ ayat (2). Jika hanya nendasarkan pada asas kepastian hukum, tepatnya pada formal dan prosedural semata, maka manipulasi bisa dilakukan oleh pihak yang punya otoritas untuk memutus dengan cara memilih perspektif dan teori serta dalil-dalil sesuai selera dan kehendaknya sendiri.

\section{B. Saran}

Dari uraian penulis diatas, dapat lah kita pahami permasalahan tumpang tindih antar lembaga negara, yang mempunyai banyak faktor penyebab, dengan demikian Penulis memiliki saran-saran sebagai berikut:

1. Pemerintah dan DPR sebagai lembaga yang diberikan wewenang oleh UUD 1945 untuk menyusun, merancang, dan membuat peraturan perundang-undangan haruslah sesuai dengan kebutuhan, kepentingan dan perkembangan masyarakat sebagaimana tujuan dari konstitusi untuk mensejahterakan masyarakat dan menjadi negara yang adil sejahtera, makmur dan sentosa.

2. Ketika menyusun peraturan perundang-undangan hendaknya diteliti, dikaji secara mendalam sampai matang yang menyangkut segala kepentingan mansyarakat dan negara sehingga mewujudkan peraturan yang bersifat nasional dan komprehensif. Jangan terkesan asal-asalan, asal jadi, atau karena pesanan oleh pihak-pihak tertentu. Sehingga banyak UU yang baru berlaku harus sudah di amandemen atau di yudisial review karena isinya bertentangan dengan konstitusi atau tidak sesuai dengan kebutuhan masyarakat.

3. Lembaga-lembaga negara hendaknya saling menyadari hak, kewajiban, dan tugas masing-masing sehingga terjalin harmonisasi antar lembaga negara yang saling menghargai dan menghormati tugas masing-masing demi pengabdian kepada bangsa dan negara. 


\section{DAFTAR PUSTAKA}

Asshiddiqie, Jimly, Sengketa Kewenangan Konstitusional Lembaga Negara, Jakarta, Konstitusi Press, 2006.

Arinanto, Satya, Kumpulan Materi Kuliah Politik Hukum (disusun dari berbagai sumber kepustakaan), Jakarta, FH-UI, 2003.

Budiadjo, Miriam, Dasar-dasar Ilmu Politik, Jakarta, PT. Gramedia Pustaka Utama, 2006.

Buletin Komisi Yudisial, Mendorong Terwujudnya Kekuasaan Kehakiman Yang Merdeka, Jakarta, Komisi Yudisial RI, 2007.

Komisi Yudisial, Bunga Rampai Komisi Yudisial dan Reformasi Peradilan, Jakarta, Komisi Yudisial RI, 2007.

Keterangan para saksi dari mantan Anggota Panitia Ad Hoc (PAH) I Badan Pekerja MPR dalam putusan Mahkamah Konstitusi Nomor: 005/PUUIV/2006 dalam perkara permohonan uji materi terhadap UU No. 22 Tahun 2004 tentang Komisi Yudisial.

Mahfud MD, Perdebatan Hukum Tata Negara Pasca Amandemen UUD 1945, Jakarta, LP3ES, 2007.

Media Indonesia, Uji Materil UU Pemilu, Kewenangan MK dipersoalkan, (Rabu, 30 April, 2008).

Putusan Mahkamah Konstitusi RI Nomor 005/PPU-IV/2006 tentang Yudisial Review Undang-undang No.22 Tahun 2004 tentang Komisi Yudisial.

Putusan Mahkamah Konstitusi RI Nomor 006/PPU-III/2005 tentang Penentuan Syarat-syarat kerugian konstitusional.

Putusan Mahkamah Konstitusi No.017/PUU-III/2005 tanggal 6 Januari 2006.

Soemantri, Sri, Bunga Rampai Hukum Tata Negara Indonesia, 1978, dan Mahfud MD, Membangun Politik Hukum, Menegakkan Konstitusi, 2006.

Undang-Undang Dasar 1945.

Undang-Undang No.22 Tahun 2004 tentang Komisi Yudisial.

Undang-Undang No.24 Tahun 2003 tentang Mahkamah Konstitusi.

Undang-undang No. 4 Tahun 2004 tentang Kekuasaaan Kehakiman jo UU No. 5 Tahun 2004 tentang Perubahan atas UU No. 14 Tahun 1985 tentang Mahkamah Agung. 